\title{
AN EXPLORATORY STUDY IN AIRLINE AND BANKING CALl CENTRE IN INDONESIA TOWARDBUSINESS PROCESS OUTSOURCING FRAMEWORK
}

\author{
Idayanti Nursyamsi ${ }^{1}$ \\ ${ }^{1}$ Assistant Professor, Department of Management, \\ Faculty of Economics and Business, \\ Universitas Hasanuddin, Indonesia
}

\begin{abstract}
As BPO firms plan to execute various types of processes in an offshore model, they face a host of decisions regarding different resources. Amongst the most crucial resources for these processes is information availability. Information is the vital connecting link between the client and the human and locational resources of the BPO firms. Some Business Process Outsourcing (BPO) vendors are providing Information Technology (IT) Enabled Process Outsourcing and Reengineering service to clients. IT Enabled Process Outsourcing and Reengineering of tasks and reports printing function can result in the strategic benefit of better customer response time derived from a dramatic decrease in cycle time. This approach can result in significant cost savings. This paper sets out the issues in managing information in two different contexts of Direct Customer Interaction and Routine back-office. By analyzing communication, information retrieval and information distribution activities, it develops a framework for a deeper exploration of each type of outsourcing.
\end{abstract}

\section{KEYWORDS}

Business process outsourcing, call centre, communication, information retrieval, information distribution

\section{INTRODUCTION}

Business Process Outsourcing (BPO) has transcended its origins as low-cost technical operations to cover increasingly complex business processes, such as credit card processing, customer interaction and data mining \& analysis. This is largely driven by the twin engines of search for strategic competitive advantage, and ever-increasing developments in information technology. BPO occurs when an organization turns over the management and optimization of a business function, such as accounts payable or purchasing, to a third party that conducts the activity based on a set of predetermined performance metrics.

Though some forms of BPO may include both IT management and business operations, the term BPO primarily is about turning over functions such as payroll, accounting, billing or even real estate management to a third party. Though these business processes may depend on IT, they are separate functions from core IT operations, such as data center activities or network management (Dash, 2001). Initially, offshore outsourcing was restricted to fairly technical tasks such as database tuning and data scrubbing, which had no strategic implications. 
However, there has been a steady movement along the knowledge continuum in the direction of increasing expertise and information-intensiveness in the nature of the work that is being outsourced today (Aron and Singh, 2003). The different types of knowledge work that go into a BPO can be broadly categorized as (Ramachandran and Voleti, 2004) are (1) Data entry and conversion which includes medical transcription; (2) Rule Set Processing in which the information worker makes judgement based on a set of rules provided by the client; (3) Problem solving in which the information worker has more discretion, the rules here are fluid and less amenable to structuring than in the rule-set processing genre; (4) Direct customer interaction in which the information worker handles more elaborate interaction with the client's customers; and (5) Expert 'knowledge services' which require specialists and are similar to services offered by consultants.

\section{LOGISTICS ISSUES AND ANALYSES}

Logistics Management is defined as "that part of the supply chain process that plans, implements, and controls the efficient, effective flow and storage of goods, services, and related information from the point of origin to the point of consumption in order to meet customers' requirements" (CSCMP, 2014; Larson and Halldorsson, 2003). This definition includes the flow of materials and services in both the manufacturing and service sectors. Logistics is dependant upon natural resources (land, facilities, and equipment), human resources, financial resources, and information resources for inputs (Lambert, Stock and Ellram, 2003).

The challenge, and opportunity, for new information and communication technologies is to deliver the right information to the right person at the right time (Mitchell , 2002) using communication, information retrieval, and information distribution (Björk, 2002; Fabbe-Costes, 1997). By its very nature, this comprises integration activities and is well supported by IT tools.

A study of logistics issues is crucial for effective execution of any process. As BPO processes are information-intensive, there is a need to study the issues faced by various types of outsourced processes. Identifying different logistical issues at different levels of knowledge work along the continuum provides a useful starting point for a more detailed examination of the information logistics at each level of operation.

The BPO sector in Indonesia has grown significantly in the recent years, and industry analysts such as Gartner, and IDC are forecasting astronomical growth in this sector over the next five years. Companies have long outsourced manufacturing operations and other tasks such as IT maintenance or software development. However, of late, there has been a steady movement along the knowledge continuum in the direction of increasing expertise and informationintensiveness in the nature of the work that is being outsourced today. The knowledge continuum can be thought of as having a 'data origin' and a 'knowledge end' which service the decision makers within a corporation (Aron and Singh, 2003).

Logistics has become an increasing area of strategic concern for firms (e.g. Bowersox, Mentzer and Speh, 1995; Bowersox et al., 1992; Bowersox et al., 1989; Michigan State University Global Logistics Research Team, 1995; Stalk, Evans and Shulman, 1992). Acknowledging the dramatic changes in the economy, which has become more information intensive, more global and more dependent on technology, several authors, both inside and outside the logistics discipline, have indicated the importance of logistics as a source of sustainable competitive advantage (Achrol, 1991; Day, 1994; Porter, 1985; Stalk, Evans and Shulman, 1995; Yin, 2009).

The outsourced business processes are information-intensive (the primary inputs and outputs both being in the form of information), and lend themselves to the study of logistics issues related to information availability, flow and storage. Therefore, this paper is an exploratory study 
of the implications for various types of outsourced processes along the knowledge continuum. A classification of various outsourced processes is attempted. This framework would help understand the cost and effort involved in executing the various types of outsourced processes. Two typical types of outsourced environments, voice, and non-voice, are analyzed to bring out information logistics issues in Indonesia. The outsourced environments are all located in various town in Indonesia such as The Call Centre owned by CitiLink which support the airline passanger and HSBC Premier Call Centre that support the premier customer enquiry particulary on their HSBC Credit Card.

\subsection{CitiLink Call Centre Environment}

Types of activities handled:

The inbound calls would either require servicing or sales in the following activities:

- Service: The servicing query involves activities like making changes to a policy, issuing a fresh quote or cover notes for the policy. In case of an exception or clarification required, a note is kept by the agent on the policy account stating the status of the problem resolution.

- Sales: After the closure of the servicing activity the call centre agent could then proceed to take up sales activities which consisted mainly of either upselling or cross-selling of existing policies. This centre does not originate sales calls (which are otherwise called outbound calls in the BPO industry).

- Processing of a non -voice query in an insurance call centre: The call centre also handles non-voice queries, which may be by mail or e-mail. Both the cyber and physical mails are processed in a given turnaround time.

\section{Process flow:}

Processing of a voice query in an insurance call centre: The user first initiates a voice query when he calls one of the toll-free numbers that is available with him. The exchange at the client end then processes the call, and routes it to one of the three call centres. Based on the availability of personnel at the call centres and the skill sets of these agents, the call is routed to the appropriate centre. In the centre the call is then serviced by one of the agents.

Security: There are procedures for the verification of each call. The agent has to ensure the bonafides of the caller before processing the call.

Exception handling during the calls: If the activities handled in the call centre are largely routine activities, most of the scenarios can be anticipated by extensive process detailing. In case of doubts of how to process a particular query, the onsite manager usually has the expertise to resolve the query. Some queries are deferred as they have to be referred to the parent organization. The process flow is represented in Figure 2.

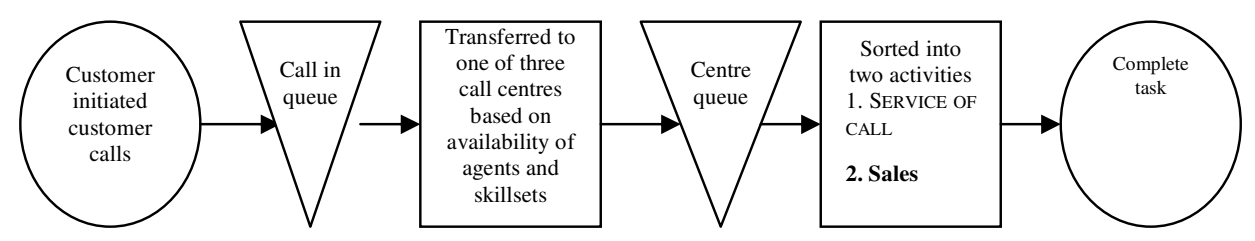

Figure 2. Flow of information in a voice query in the call center 


\section{Performance:}

The detailed call receiving process has to be completed within a maximum time limit. There is a Service Level Agreement (SLA) regarding the time in which an agent picks up the call.

- Service level agreements: The performance of the call center is assessed on the basis of (1) Revenues generated for the client; (2) Turnaround time for processing a call; (3) Average and maximum time duration of calls; (4) Abandoned call rate- number of calls dropped after being routed to the centre; and (5) Call Answer rate-dependent on abandoned call rate as well as the maximum time duration of each call.

- Quality checks and controls: Query resolution being an oft encountered task in customer interface, strict quality is introduced to ensure compliance with the given script. Any agent has random checks by the quality manager. Apart from that, there are periodic random checks by the parent office. All calls are recorded, and are required to be stored for a year in case of complaints or litigation.

\section{Information implications:}

The process flow clearly shows that there are queues and the description shows that the entire customer interaction has to be satisfactorily closed within the given time. This along with the SLA requirements of the call answer rate and abandoned rate highlight the importance of "communication" as all calls are serviced in real time due to the mode of operation. This also necessitates ensuring adequate bandwidth as well agent time to ensure that maximum number of queries is serviced.

It is necessary for the agent to be able to access latest account information to ensure successful servicing of the call. Hence, sharing and retrieval of information assume significance. Since the agents respond to users on the phone, this information retrieval needs to be near instantaneous. All information required for closing a call is supplied by the client..

\subsection{HSBC Premier Credit Card Centre Environment Types of activities handled:}

These activities consist of credit card application form filling, which is primarily a data transformation job. Activities like new credit card issuance, and account closure consists of operations based on a set of rules clearly laid out by the client, and generally do not involve much discretion of the provider. However, some activities like risk sorting, and collections require more decision making by the provider, and could be classified under the Problem Solving category.

\section{Process flow:}

The non-voice operations are largely constrained by the availability of online application, which is managed at the customer end. The process is triggered off by credit card centre receiving scanned documents, emails or physical mail. The agents generally use these as inputs to their processes. The process flow is represented in Figure 3. The activities handled by this process are largely routine activities, and are amenable to extensive process detailing. 


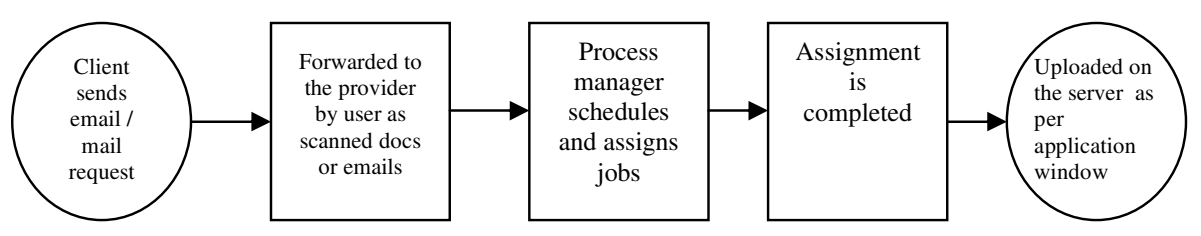

Figure 3: Flow of Information in An Outsourced Non-voice Operation

\section{Performance:}

Performance measures are agent productivity (i.e. time taken per application), and quality (i.e. number of errors made by an agent in a batch of application processed). Turn around time of a batch of work is also tracked.

\section{Information implications:}

Implications are based on the three aspects of communication, information retrieval and information distribution. It is found that in this case, real time information exchange is not critical. Information retrieval and updating of databases is important, but that too is not required at real time. Since these are activities are routine, well defined and process driven the information distribution aspect is provided by the client. All forecasts and required information is given by the client.

\section{RESULTS AND DISCUSSION}

Based on the above, a comparison of information implications for various types of outsourced processes is summarized in the Table 1. 
Table 1. Information issues in outsourced process types.

\begin{tabular}{|c|c|c|c|}
\hline \multirow{2}{*}{$\begin{array}{l}\text { Process } \\
\text { types }\end{array}$} & \multicolumn{3}{|c|}{ Information Logistics requirements } \\
\hline & Communication & Information Retrieval & Information Distribution \\
\hline $\begin{array}{l}\text { Direct } \\
\text { customer } \\
\text { interaction }\end{array}$ & $\begin{array}{l}\text { - High level of integration } \\
\text { between the client's } \\
\text { system and the } \\
\text { provider's. } \\
\text { - Two-way } \\
\text { communication required } \\
\text { on a real time basis }\end{array}$ & $\begin{array}{l}\text { - Very high speed } \\
\text { required. Crucial for the } \\
\text { process. } \\
\text { - Standardised } \\
\text { information made } \\
\text { available by client as a } \\
\text { database } \\
\end{array}$ & $\begin{array}{l}\text { All information supplied by } \\
\text { client i.e. client driven }\end{array}$ \\
\hline $\begin{array}{l}\text { Data entry } \\
\text { and } \\
\text { conversion }\end{array}$ & $\begin{array}{l}\text { - Limited integration } \\
\text { between the client's } \\
\text { MIS and the provider's. } \\
\text { - Data transformation at } \\
\text { the provider's site and } \\
\text { uploaded on to the } \\
\text { client's systems in batch } \\
\text { processing mode. }\end{array}$ & $\begin{array}{l}\text { - Information retrieval } \\
\text { speed is not crucial } \\
\text { - Standardised } \\
\text { information made } \\
\text { available by client on } \\
\text { easily accessible } \\
\text { databases }\end{array}$ & $\begin{array}{l}\text { All information supplied by } \\
\text { client i.e. client driven }\end{array}$ \\
\hline $\begin{array}{l}\text { Rule-set } \\
\text { processing }\end{array}$ & $\begin{array}{l}\text { - Limited integration } \\
\text { between the client's } \\
\text { MIS and the provider's. } \\
\text { - Processing at the } \\
\text { provider's site and } \\
\text { uploaded in batch } \\
\text { processing } \\
\text { mode.Clarification in } \\
\text { specific cases }\end{array}$ & $\begin{array}{l}\text { - Information esp. rules } \\
\text { retrieval speed is } \\
\text { important. } \\
\text { - Standardised } \\
\text { information made } \\
\text { available by client on } \\
\text { easily accessible } \\
\text { databases }\end{array}$ & $\begin{array}{l}\text { All information supplied by } \\
\text { client i.e. client driven }\end{array}$ \\
\hline $\begin{array}{l}\text { Problem } \\
\text { solving }\end{array}$ & $\begin{array}{l}\text { - Substantial integration } \\
\text { between the client's } \\
\text { MIS and the provider's. } \\
\text { - Operations at the } \\
\text { provider's site and } \\
\text { uploaded in batch } \\
\text { processing mode. } \\
\text { - More interaction for } \\
\text { purposes of } \\
\text { clarification. }\end{array}$ & $\begin{array}{l}\text { - Information retrieval } \\
\text { speed is not crucial } \\
\text { - Basic information made } \\
\text { available by client on } \\
\text { easily accessible } \\
\text { databases }\end{array}$ & $\begin{array}{l}\text { - Most of the information } \\
\text { supplied by client. }\end{array}$ \\
\hline $\begin{array}{l}\text { Expert } \\
\text { 'knowledge' } \\
\text { services }\end{array}$ & $\begin{array}{l}\text { - Limited integration } \\
\text { between the client's } \\
\text { MIS and the provider's. } \\
\text { - Operations at the } \\
\text { provider's site and then } \\
\text { uploaded in batch } \\
\text { processing mode. } \\
\text { - More interaction for } \\
\text { information collection } \\
\text { and clarification. }\end{array}$ & $\begin{array}{l}\text { - Information retrieval } \\
\text { speed is not crucial } \\
\text { - Basic information made } \\
\text { available by client on } \\
\text { easily accessible } \\
\text { databases }\end{array}$ & $\begin{array}{l}\text { - Provider to anticipate } \\
\text { information from the } \\
\text { client. }\end{array}$ \\
\hline
\end{tabular}

The above table for various outsourced operations may be plotted on a graph with axes as quantum of information logistics vs. knowledge, as shown in Figure 4. 


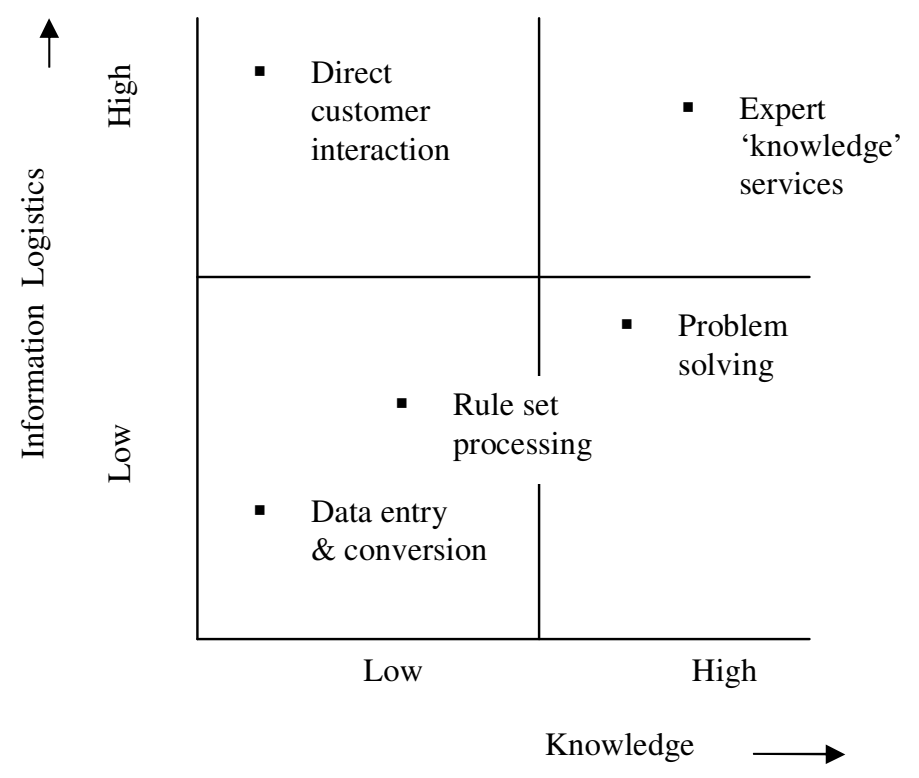

Figure 4. Information logistics and knowledge matrix

Based on Figure 4, no real time communication requirements, speed of information retrieval not being critical, and information distribution done entirely by the client has been classified as low information logistics requirements. Real time communication, and speed of information retrieval being critical, and information largely required to be anticipated by the client has been classified as high information logistics requirements. This explains the continuum represented by the Yaxis in Figure 4. The $\mathrm{X}$-axis represents the knowledge continuum, with a data origin at the extreme left, and knowledge at the extreme right. The various outsourced operations discussed are positioned as shown below.

Direct Customer Interaction or call centre kind of operations have near real time information requirements, and hence are very high on Information Logistics issues, but being routine jobs are low on the knowledge factor. Non voice operations like data entry and rule set processing are client driven routine processes operating in a batch mode; hence, they are low on information logistics issues as well as knowledge requirements. Problem solving operations e.g. risk sorting are high on knowledge requirements, but being offline and client-driven are low on information logistics issues. This is however, case specific. If the problem solving process in question requires information anticipation by the provider, then it could also be high on the information logistics scale, and in the same quadrant as Expert Services. Expert services are high on both knowledge and information logistics requirements.

The cost of an activity is the direct result of the consumption of resources [8]. In the current context, one of the important resources is information. Therefore, the processes high on information logistics imply higher cost and effort of execution.

\section{CONCLUSIONS}

This study classifies the various types of outsourced operations based on their information requirements. This framework could be useful for understanding cost and effort involved in execution of various types of outsourced processes in call center environment. This study may 
well be the first to throughfully examined the call centre and offshored centre environment in Indonesia in order to build BPO framework that might help others in their respective field of research and practice.Future research could be geared toward examining other business environment such as offshored outsourcing environment.

\section{REFERENCES}

1. Achrol, R (1991). Evolution of the marketing organization: new forms for turbulent environments, Journal of Marketing, vol. 55, no. 4, pp. 77-93.

2. Aron, R and Singh, J (2003). IT Enabled Strategic Outsourcing: Knowledge Intensive Firms, Information Work and the Extended Organizational Form, Knowledge@ Wharton, The Wharton School, University of Pennsylvania.

3. Björk, BC (September 2002). A formalised model of the information and materials handling activities in the construction process, Construction Innovation, vol. 2, issue 3, p. 133-149

4. 4.Bowersox, DJ, Mentzer, JT and Speh, TW (1995). Logistics leverage, Journal of Business Strategies, vol. 12, no. 2, pp. 36-49.

5. 5.Bowersox, DJ, Daugherty, PJ, Dröge, CL, Rogers, DS and Wardlow, DL (1989). Leading Edge Logistics: Competitive Positioning for the 1990s, The Council of Logistics Management, Oak Brook, IL.

6. 6.Bowersox, DJ, Daugherty, PJ, Dröge, CL, Germain, RN and Rogers, DS (1992). Logistical Excellence: It's Not Business as Usual, Digital Press, Burlington, MA.

7. 7.CSCMP (Council of Supply Chains Management Professionals),www.clm1.orgAccessed 12 February 2014.

8. 8.Dash, J (2001). Business process outsourcing, Computerworld, 1/1/2001, vol. 35, issue 1.

9. 9.Day, GS (1994). The capabilities of market-driven organizations, Journal of Marketing, vol. 58, no. 4 , pp. $37-52$.

10. 10.Fabbe-Costes, N (June 1997). Information management in the logistics service industry, Transport Logistics, vol. 1, issue 2, p. 115-128.

11. 11.Lambert, DM, Stock JRand Ellram LM (1998). Fundamentals of Logistics Management, Irwin/McGraw-Hill, Singapore.

12. 12. Larson PD and Halldorsson A (March 2003). Logistics versus supply chain management: an international survey, International Journal of Logistics: Research and Applications, vol. 7, no. 1, pp17-31.

13. 13.Michigan State University Global Logistics Research Team (1995). World Class Logistics: The Challenge of Managing Continuous Change, The Council of Logistics Management, Oak Brook, IL.

14. 14.Mitchell A (2002). Employing logistics without even knowing it,New Media Age, 9/12/2002, pp. 20-21.

15. 15.Porter, ME (1985). Competitive Advantage, The Free Press, New York, NY.

16. 16.Ramachandran K and Voleti S (Jan-Mar 2004). Business Process Outsourcing (BPO): Emerging Scenario and Strategic Options for IT-enabled Services, Vikalpa, vol. 29, no. 1.

17. 17.Stalk, G, Evans, P and Shulman, L (1992). Competing on capabilities: the new rules of corporate strategy, Harvard Business Review, vol. 70 no. 2, pp. 57-68.

18. 18.Yin, RK (2009). Case Study Research: Design and Methods, 4th Edition,Applied Social Research Methods Series, Sage Publications Inc., Thousand Oaks, CA. 